\title{
SPASIALISASI DAN PRAKTIK KONGLOMERASI MEDIA KELOMPOK KOMPAS GRAMEDIA
}

\author{
Rahmawati Zulfiningrum \\ Ilmu Komunikasi Universitas Dian Nuswantoro Semarang, Jl. Imam Bonjol No. \\ 207 Semarang, Telp: (024) 3517261, Email: darumzulfie@gmail.com
}

\begin{abstract}
This study aims to determine the spatialization and practices of media conglomeration by Kompas Gramedia group. This type of research is descriptive qualitative. In this research, data collection techniques used in-depth interviews, library research, and documentation. This study uses a technique Interactive Analysis Model Miles and Huberman. Spatialization as a process for overcoming space and time, map out the extent to which the media were able to present their products to the front of the reader, viewer, or consumers with the limits of space and time. The results indicate that the practice of spatialization conducted by Kompas Gramedia Group is to follow the model of industrial economy. It is characterized by the abundance of media and accelerate the results to get a low cost for the production or efficiency. This indicates the growth spirit of capitalism in the media industry. The media industry, which was built in the spirit of capitalism would produce media messages or product oriented capital increase. The conglomeration of media make the media do their efficiency is reflected in the value chain of media products. As the result, media also could not avoid about the content that will be the same. With equalizer for the content of these media, people in the audience do not have the freedom to select appropriate media content as what they want.
\end{abstract}

Keywords : spatialization, conglomeration, efficiency, content.

\begin{abstract}
Abstrak
Penelitian ini bertujuan untuk mengetahui spasialisasi dan praktik konglomerasi media kelompok Kompas Gramedia. Tipe penelitian ini adalah deskriptif kualitatif. Penelitian menggunakan teknik pengumpulan data dengan wawancara mendalam, studi pustaka, dan dokumentasi. Penelitian ini menggunakan Teknik Analisis Interaktif Model Miles dan Huberman. Spasialisasi adalah proses untuk mengatasi ruang dan waktu, memetakan sejauh mana media mampu menyajikan produknya ke hadapan pembaca, pemirsa, ataupun konsumennya dengan batasan ruang dan waktu. Hasil penelitian menunjukan bahwa praktek spasialisasi yang dilakukan oleh Kelompok Kompas Gramedia adalah dengan mengikuti model ekonomi industrial. Hal ini ditandai dengan banyaknya akselerasi media dan hasil-hasilnya untuk mendapatkan biaya yang murah untuk produksinya atau efisiensi. Hal ini menandakan tumbuhnya semangat kapitalisme dalam industri media. Industri media yang dibangun dengan semangat kapitalisme tentu akan menghasilkan pesan atau produk media yang berorientasi pada bertambahnya modal. Dengan adanya konglomerasi media, efisiensi yang dilakukan media tergambar pada rantai nilai produk media (media product value chain). Hasilnya, media juga tidak bisa mengelak mengenai isi pemberitaan yang akan cenderung sama. Dengan penyamaan atas isi media ini, masyarakat sebagai audiens tidak memiliki kebebasan untuk memilih konten media sesuai dengan yang mereka inginkan.
\end{abstract}

Kata kunci : Spasialisasi, konglomerasi, efisiensi, konten. 


\section{Pendahuluan}

Perhatian ekonomi politik diarahkan pada kepemilikan, kontrol serta kekuatan operasional pasar media. Dari titik pandang ini, institusi media massa dianggap sebagai sistem ekonomi yang berhubungan erat dengan sistem politik. Karakter utama pendekatan ekonomi politik adalah produksi media yang ditentukan oleh pertukaran nilai isi media yang sangat beragam di bawah kondisi tekanan ekspansi pasar yang ditentukan oleh kepentingan ekonomi-politik pemilik modal dan pembuat kebijakan media (McQuail, 2000:82). Proses spasialisasi pada kajian ekonomi politik, tidak terlepas dari rezim kapitalisme, karena spasialisasi ekonomi politik hadir setelah perkembangan kapitalisme yang mendominasi peradaban dunia global. Marx berpendapat bahwa perkembangan hubungan kapitalis memiliki efek mengatasi semua hambatan spasial, serta menghapuskan ruang dan waktu. Kapitalisme adalah sebuah sistem produksi, distribusi, dan pertukaran di mana kekayaan yang terakumulasi diinvestasikan kembali oleh pemilik pribadi untuk memperoleh keuntungan. Dengan adanya kapitalisme tumbuhlah modal yang digunakan untuk memperbaiki sarana trasportasi dan komunikasi, sehingga pemanfaatan teknologi ini mampu memindahkan barang, orang dan pesan dalam waktu relatif lebih cepat (singkat) menurut pakar teori sosial Henri Lefebvre (1979:97).

Secara konseptual, Mosco memaknai spasialisasi sebagai proses untuk mengatasi ruang dan waktu, memetakan sejauh mana media mampu menyajikan produknya ke hadapan pembaca, pemirsa, ataupun konsumennya dengan batasan ruang dan waktu. Ruang tidak hanya bermakna geografis, namun juga demografis, sisi dimana struktur kelembagaan suatu media mempunyai peran yang signifikan dalam memenuhi jaringan dan kecepatannya untuk menyampaikan produknya ke hadapan publik. Spasialisasi merupakan proses perpanjangan institusional media melalui bentuk korporasi dan besarnya badan usaha media (Mosco, 1996:5).

Ukuran badan usaha media dapat bersifat horizontal maupun vertikal. Horizontal yaitu bentuk badan usaha media tersebut adalah bentuk-bentuk konglomerasi dan monopoli. Integrasi horizontal adalah sebuah perusahaanperusahaan media yang memiliki sekaligus bisnis lain yang tidak ada hubungannya dengan bisnis media, seperti hotel, rumah makan dan lainnya. Sedangkan proses spasialisasi yang bersifat vertikal adalah proses integrasi antara induk perusahaan dan anak perusahaannya yang dilakukan dalam satu garis bisnis untuk memperoleh sinergi, terutama untuk memperoleh kontrol dalam produksi media. Luas dan besarnya kepemilikan media di tangan konglomerat atau pemegang kekuasaan telah membuat media menjadi lebih terintegrasi pada kepentingan pemilik serta memperdalam ikatan mereka dengan kepentingan kelas kapitalis. Kecenderungan yang paling terlihat di antara perusahaan media saat ini adalah integrasi vertikal yang merupakan suatu usaha dimana sebuah perusahaan menguasai beberapa aspek yang berhubungan dengan bisnis media sekaligus dengan masing-masing bagian saling membantu. Banyak perusahaan media yang memiliki lebih dari satu jenis usaha: surat kabar, majalah, stasiun radio, televisi dan media online (Shirley, 2010:14).

Demikian pula halnya dengan apa yang terjadi pada bisnis media cetak yang hanya dikuasai oleh empat pemain besar media, yaitu Kelompok Kompas Gramedia, Group Femina, Group Tempo, dan Jawa Pos. Dapat dilihat bahwa bentuk pasar media massa di Indonesia merupakan bentuk pasar oligopoli. Integrasi horizontal di bawah naungan suatu holding company kepemilikan media di Indonesia sangat sulit 
dibatasi dan walaupun memiliki berbagai sisi negatif, integrasi horizontal ini memang masih diperlukan dalam menghadapi kondisi pasar global. Sekarang ini telah terbentuk setidaknya dua kelompok besar konglomerasi media cetak, karena adanya ekspansi yang agresif dari dua pemain besar media cetak ini yakni Kelompok Kompas Gramedia dan Kelompok Jawa Pos. Konglomerasi media pertama adalah Kelompok Kompas Gramedia yang di miliki oleh Jacob Oetama dan yang kedua adalah Jawa Pos Group yang dimiliki oleh Dahlan Iskan. Kompas memulai tradisi berbisnis koran dengan sangat-sangat proper. Berhati-hati sekali, hingga kehati-hatian itu tercermin dalam editorial policy mereka, pada paruh dekade 90-an, Kompas dikenal sebagai koran yang "bermain aman" (safety player newspaper). Kemapanan, kehatihatian, dan kesantunan, adalah karakter menonjol dari Kompas. Hal ini bisa jadi merupakan refleksi dari kepemimpinan Jakob Oetama, sebagai sosok yang santun, menjunjung tinggi harmoni dan sebaliknya menjauhi konflik.

\section{Salah Satu Raksasa Grup Media Cetak di Indonesia}

\section{KOMPAS GRAMEDIA}

Gambar 1. Logo Kompas Gramedia Group

Kompas Gramedia merupakan grup bisnis media milik Jacob Oetama. Mantan pemimpin redaksi harian Pedoman Rosihan Anwar pernah menyebut jenis jurnalisme Kompas ini sebagai "jurnalisme kepiting". Maksudnya, kepribadian Kompas bergerak ala kepiting, mencoba melangkah setapak demi setapak untuk mengetes seberapa jauh kekuasaan memberikan toleransi kebebasan pers yang ada. Jika aman, kaki kepiting bisa maju beberapa langkah, jika kondisi tak memungkinkan, kaki kepiting pun bisa mundur beberapa langkah. Karena kekepitingannya atau kehati-hatiannya itulah sampai hari ini Kompas bisa bertahan, malah makin bertambah besar ketika masa jurnalisme kepiting telah berlalu.

Kompas Gramedia memiliki beberapa anak media yang tersebar hampir di seluruh daerah di indonesia dengan berbagai bentuk media, diantaranya televisi, koran, majalah, tabloid, dan radio. Untuk media televisi, grup ini memiliki KOMPAS TV sebagai televisi lokal berjaringan dengan 12 jumlah izin, 6 televisi merupakan stasiun on-air yaitu, Denpasar (Dewata TV), Surabaya, Semarang (Borobudur TV), Bandung (FTV), Tangerang (Komedi TV), dan Pontianak (Kathulistiwa TV), sementara 6 telavisi lainnya merupakan stasiun licence antara lain, Medan, Palembang, Cirebon, Garut, Purworejo, dan Yogyakarta.

Untuk koran skala nasional, Kompas Gramedia memiliki dua media yaitu KOMPAS dan Kontan. Warta Kota, Warta Jateng, Berita Kota, Surya, dan 22 koran Kelompok Persda untuk skala regional.

Untuk jenis majalah dan tabloid, tidak kurang dari 80 nama yang dimiliki diantaranya untuk majalah; Majalah BOBO, Angkasa, NGI, InStyle dan tabloid; Bola, PC Plus, dan lain-lain. Sedangkan untuk media radio Kompas Gramedia Grup memiliki stasiun-stasiun seperti Motion dan Sonora yang ada dibeberapa kota, serta beberapa percetakan.

\section{Metode Penelitian}

Tipe penelitian ini adalah deskriptif kualitatif, mengenai Spasialisasi dan Praktik Konglomerasi Media Kelompok Kompas Gramedia. Dalam penelitian ini digunakan teknik pengumpulan data wawancara mendalam, studi pustaka, dan dokumentasi. Penelitian ini menggunakan Teknik Analisis Interaktif Model Miles dan Huberman. Pandangan ini menyatakan terdapat tiga alur kegiatan yang terjadi 
secara bersamaan yaitu reduksi data, penyajian data, dan penarikan kesimpulan atau verifikasi, yang merupakan proses siklus dan interaktif.

Dilihat dari sudut pandang ekonomi politik media, kondisi media kontemporer saat ini ditandai dengan meluasnya konsentrasi dan konglomerasi media. Di satu sisi tumbuh media dalam berbagai lini yang berbeda, namun di sisi yang lain, kepemilikan dari media semakin memusat pada segelintir orang saja. Baik di tingkat nasional maupun internasional, ada tendensi yang mengarah pada konsentrasi kepemilikan media massa oleh konglomerat media transnasional. Akibatnya semakin mengecilnya ruang publik media massa karena semakin terkonsentrasinya media massa.

Kondisi ini sekarang terjadi di Indonesia. Penulis akan menganalisis praktek konglomerasi dalam tubuh Kelompok Kompas Gramedia. Terutama berkaitan dengan sejauh mana Kelompok Kompas Gramedia menampilkan diri dalam batasan ruang dan waktu yang dalam ekonomi politik komunikasi merupakan bahasan dalam segmen spasialiasi. Pada poin ini maka struktur kelembagaan media menentukan perannya di dalam memenuhi jaringan dan kecepatan penyampaian produk media di hadapan khalayak. Sehingga perbincangan mengenai spasialisasi tak bisa lepas dengan bagaimana bentuk korporasi dan konglomerasi dari Kelompok Kompas Gramedia. Kedua, pertanyaan yang berkaitan dengan efisiensi produksi dan diversity of content sebagai dampak dari konglomerasi dimana dengan adanya konglomerasi, media juga tidak bisa mengelak mengenai isi pemberitaan yang akan cenderung sama.

\section{Hasil Penelitian dan Pembahasan \\ Profil Kelompok Kompas Gramedia Group}

Kelompok Kompas Gramedia adalah salah satu perusahaan di Indonesia yang bergerak di bidang media massa yang didirikan pada tanggal 28 Juni 1965 oleh PK Ojong dan Jakob Oetama. Pada tahun 1980an usaha mereka mulai dikembangkan, terutama dalam bidang komunikasi. KG memiliki beberapa anak perusahaan atau bisnis unit yang bervariatif dari media massa, toko buku, percetakan, radio, hotel, lembaga pendidikan, event organizer, stasiun TV hingga Universitas.

Pada tahun 2005, perusahaan ini mempekerjakan sekitar 12.000 karyawan yang tersebar di seluruh Indonesia. Saat ini, KKG terbagi atas beberapa anak perusahaan, yaitu: Surat kabar yang berbasis nasional (Kompas) dan daerah (Tribun), Warta Kota, Harian Surya. Majalah (National Geographic, Hai, bobo, kawanku, chip, info komputer, angkasa, what hifi\&home cinema, hot game, idea). Tabloid (nova, sedap, saji, PC Plus, Bola, Soccer, motorplus). Media online (Kompas.com), tribunnews.com, Kompas e-paper yaitu bentuk digital dari harian Kompas. Radio (Sonora), selain bergerak dibidang media, KKG juga memiliki Jaringan percetakan (PT Gramedia Printing Group: (Palmerah, Cikarang, Bandung, Bali), PT Bawen Media Tama (Semarang), PT Medan Media Grafika Tama (Medan), PT Rambang (Palembang), PT Antar Surya Jaya (Surabaya). Jaringan Penerbit Buku (Gramedia Pustaka Utama, Elex Media Komputindo, Penerbit Buku Kompas, Kepustakaan Populer Gramedia, Gramedia Widiasarana Indonesia ). Jaringan toko buku (Gramedia). Jaringan hotel (Amaris, Santika, Kayana). Event organizer (Dyandra Promosindo). Industri (PT Graha Kerindo Utama yang memproduksi tissue Tessa) dan dalam bidang pendidikan (Universitas Multimedia Nusantara dan ELTI Gramedia (English Language Training International)). Pada perusahaan KKG terlihat jelas bahwa terdapat praktek konglomerasi baik dari sisi integrasi vertikal 
maupun horizontal, dimana sebuah perusahaan yang memiliki media juga sekaligus memiliki lahan bisnis lain yang tidak berhubungan dengan bisnis media.

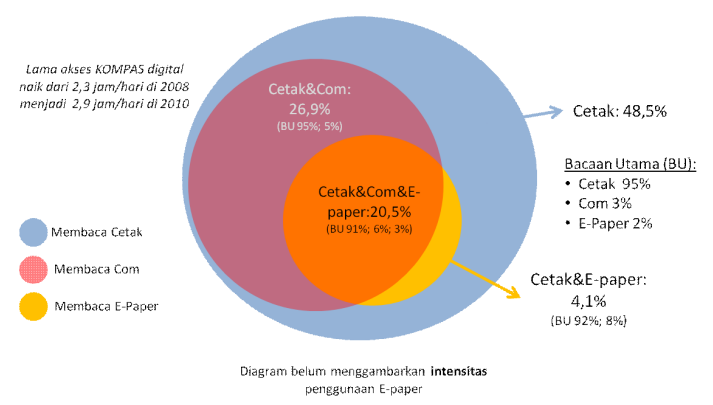

Gambar 2. Data Pengelompokan Pembaca Kompas Cetak

Awal berdirinya Kelompok Kompas Gramedia (KKG) diawali dengan diterbitkannya Majalah Intisari pada tahun 1963. Dua tahun kemudian, tepatnya tanggal 28 Juni 1965, diterbitkanlah sebuah koran baru bernama Kompas oleh PK Ojong (alm), Jakob Oetama (saat ini Presdir KKG) dan kawan-kawan. Saat ini Kompas terkenal sebagai koran berskala nasional terbesar di Indonesia, dengan oplah lebih dari 600.000 per-hari. Dengan idealisme dan semangat untuk memberikan informasi yang objektif kepada masyarakat. Kelompok Kompas Gramedia (KKG) mengkhususkan diri untuk bergerak di bidang media komunikasi, baik melalui media cetak maupun audiovisual. Baru pada sekitar tahun 80-an, Kelompok Kompas Gramedia mulai melakukan diversifikasi usaha, di luar bidang utamanya. Seiring dengan pesatnya pertumbuhan dan perkembangan bisnis perusahaan, secara struktur organisasi Kelompok Kompas Gramedia terbagi atas berbagai kelompok usaha (SBU) berdasarkan jenis usaha/jasa layanan yang dilakukan, seperti: Kelompok Percetakan, Kompas, Majalah, Gramedia Pustaka Utama (GPU), Penerbitan \& Multi Media (MMSP), Perdagangan \& Industri, Hotel Santika, Media Olahraga (Medior), Pers Daerah, RadioSonora, PT. Kompas Cyber Media.
Kompas Gramedia telah menetapkan sampai dengan tahun 2008 sebagai Milestone Pertama yaitu Tahapan Transformasi, dimana dilakukan berbagai pembenahan organisasi, infrastruktur, proses bisnis serta penyiapan SDM dan sistem pengelolaannya.

Tahun 2008-2012 ditetapkan sebagai Milestone Kedua yaitu Tahapan Pengembangan, dimana Kompas Gramedia sudah harus menjadi pemain global di kawasan Asia Tenggara. Tahun 2013 - 2016 ditetapkan sebagai Milestone Ketigayang dinamakan Tahapan Integrasi dimana setiap unit bisnis harus mencapai sinergi yang paling optimal di kawasan Asia Tenggara. Kemudian tahun 2017-2020 ditetapkan sebagai Milestone Keempat bernama Tahapan Akreditasi, dimana Kompas Gramedia memantapkan pencapaian visi 2020 dan mulai merumuskan visi baru Kompas Gramedia 2040 .

Untuk mencapai sasaran strategis korporat pada tahapan pengembangan, maka disusunlah Roadmap Coorporate tahun 2008-2012. Roadmap ini menetapkan beberapa inisiatif strategis korporat seperti adanya grouping bisnis unit media selambatlambatnya di tahun 2009. Juga melakukan optimalisasi revenue secara korporat dengan penjualan bersama melalui pembentukan corporate advertising (komisi iklan) dan corporate circulation. Inisiatif korporat lain yang dilakukan untuk merambah pasar Asia Tenggara yakni melalui ekspansi pasar oleh kelompok Toko Buku, Perhotelan, PBMM, Media dan Percetakan. Dengan berbagai inisiatif strategis tersebut pada tahun 2012 ditargetkan pencapaian laba operasi korporat mencapai tiga kali lipat laba operasi di tahun 2008, sedangkan laba operasi pada tahun 2008 ini harus mencapai dua kali lipat laba operasi di tahun 2004. Secara detail Roadmap Coorporate 2008-2012 tersebut dapat dilihat pada Tabel1. 
Tabel 1. Roadmap Kompas Gramedia 2008-2012

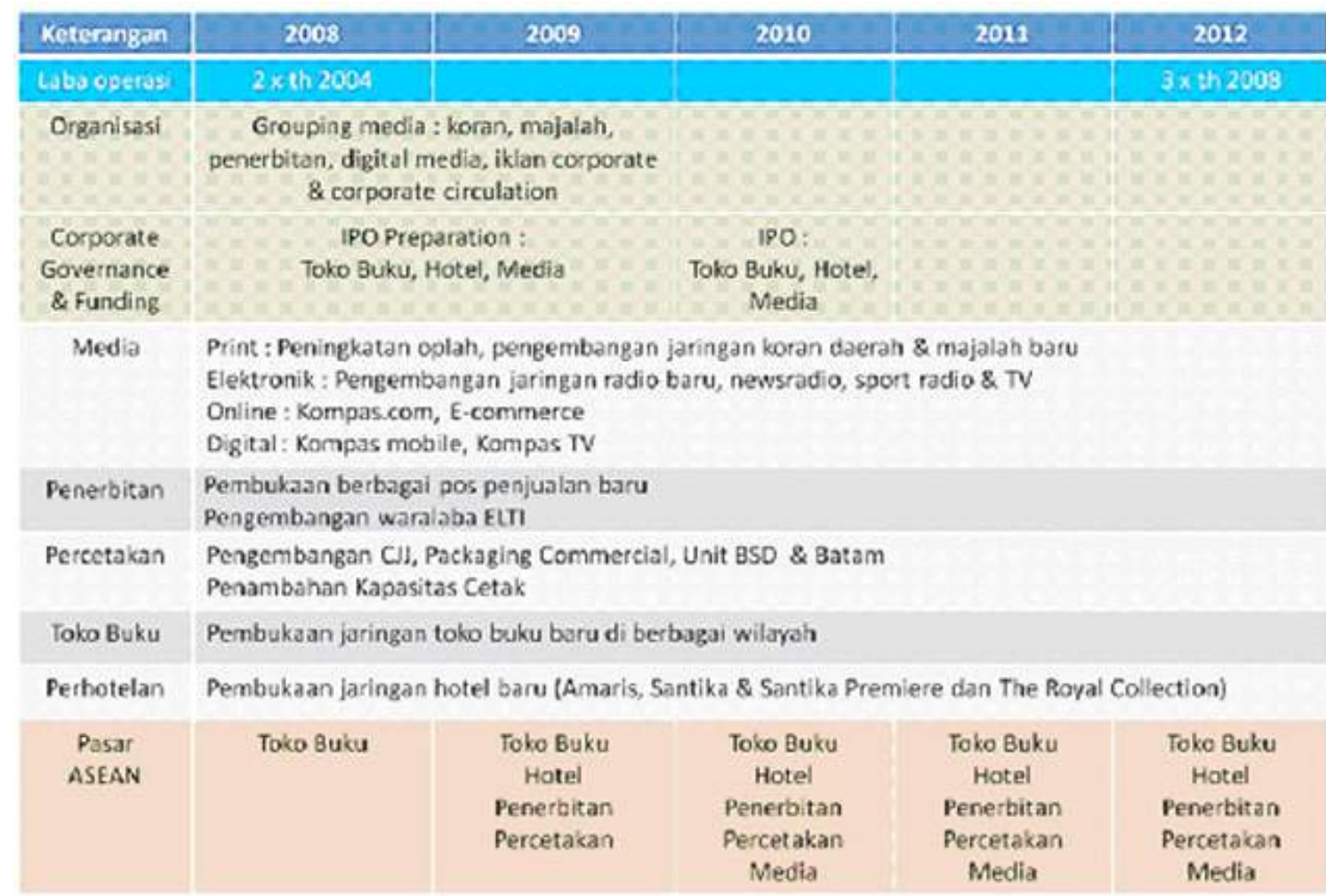

Menurut Vincent Moscow dalam bukunya The Political Economy of Communication (1998), pendekatan dengan teori ini intinya adalah ekonomi politik sebagai studi mengenai relasi sosial, khususnya relasi kekuasaan, seperti produksi, distribusi dan konsumsi sumber daya. Seperti teori Marxisme Klasik, teori ini menganggap kepemilikan media yang ada pada segelintir elite pengusaha menyebabkan patologi atau penyakit sosial. Perhatian ekonomi politik diarahkan pada kepemilikan, kontrol serta kekuatan operasional pasar media. Karakter utama pendekatan ekonomi politik adalah produksi media yang ditentukan oleh pertukaran nilai isi media yang berbagai macam di bawah kondisi tekanan ekspansi pasar dan juga ditentukan oleh kepentingan ekonomi-politik pemilik modal dan pembuat kebijakan media. Berbagai kepentingan tersebut berkaitan dengan kebutuhan untuk memperoleh keuntungan, sebagai akibat dari kecenderungan monopolistis dan proses integrasi, baik secara vertikal maupun horizontal.

Spasialisasi terkait dengan bentuk lembaga media, apakah berbentuk korporasi dengan skala besar atau sebaliknya, berjaringan atau tidak, bersifat monopoli atau oligopoli, atau konglomerasi. Lembaga-lembaga seperti ini diatur secara politis untuk menghindari terjadinya kepemilikan yang sangat sentralistik yang akan menyebabkan terjadinya monopoli produk media. Spasialisasi dapat menciptakan peluang bagi perluasan proses produksi dan distribusi bagi perkembangan industri modern terutama regulasi-regulasi yang mengakomodir prinsip-prinsip liberal. Penggabungan dan aliansi antar media (integrasi horizontal dan vertikal) telah menciptakan timbulnya monopoli pada suatu tatanan baru, suatu kesatuan besar konglomerat yang menyimpan potensi untuk mengendalikan produksi dan arus komunikasi, informasi serta hiburan. Kajian ekonomi politik menempatkan media sebagai instrumen dominasi yang dapat digunakan oleh pemilik modal atau 
kelompok penguasa lainnya untuk memberikan arus informasi publik sesuai dengan kepentingannya dalam sistem pasar komersial.

Pemilihan kelompok Kompas Gramedia sebagai contoh untuk menganalisa proses spasialisasi dan praktik konglomerasi baik dari sisi integrasi vertikal maupun horizontal, peneliti rasa sangat tepat, karena Kelompok Kompas Gramedia memiliki beragam jaringan lahan bisnis seperti yang telas diulas pada data sebelumnya, serta memiliki beragam jaringan bisnis di luar bisnis media. Kompas juga merupakan media yang bergerak di bidang surat kabar terbesar dibandingkan dengan Jawa Pos Group, Kompas Gramedia memiliki jaringan bisnis dan mendominasi pasaran dengan oplah sekitar 400,000 lembar dan menghasilkan pendapatan dari iklan sebesar kurang lebih $\$ 200,000$ per hari. Kelompok media Kompas juga merupakan raksasa media cetak pertama yang memiliki teknologi lebih maju di banding Jawa Pos Group dalam penggunaan internet sebagai sarana baru untuk media penyebaran dan yang awal dalam pembuatan situs web yang menampilkan isi dari edisi cetaknya. Di akhir 1997 kelompok ini melangkah lebih lanjut dengan membuka divisi online, Kompas Cyber Media, dan membuat portal berita internet, www.kompas.com. Saat ini situs webnya merupakan salah satu situs berita yang populer di negeri ini, yang hanya dikalahkan oleh pemuka situs online, Detik (www.detik.com).

\section{Perspektif Ekonomi Politik - Instrumentalis dan Kritis}

Perspektif ekonomi-politik kritis memiliki tiga varian utama. Ketiga varian tersebut adalah instrumentalisme, kulturalisme, dan strukturalisme. Posisi penulis dalam pembahasan ini ada pada posisi Instrumentalis yaitu melihat media sebagai kendaraan politik. Kita dapat menarik garis besar praktik konglomerasi kepemilikan media massa yang berpusat pada segelintir orang, selain memiliki perusahaan dalam bidang media, mereka juga memiliki perusahaan yang bergerak dalam bidang-bidang bisnis lain. Kaum instrumentalis menyatakan bahwa kepemilikan media secara privat merupakan instrumen dominasi kelas (Currant \& Guravitch, ed.1991). Media berfungsi menggerakkan dukungan untuk kepentingan kelas yang berkuasa (Chomsky, 1988). Terdapat lima poin penting yang dapat digaris bawahi dan dilalui oleh pesan media yaitu, pesan media melayani kekuasaan yang mapan, diproduksi oleh suatu industri atau institusi yang terkonsentrasi pada sejumlah besar korporasi, tergantung pada sumber ekonomi utama, tergantung pada pejabat pemerintah sebagai sumber, selalu ditekan oleh kelompok penekan dan diwarnai oleh ideologi tertentu (Herman \& Chomsky, 1988; Downing, Mohammadi, 1990).

Instrumentalisme fokus pada caracara kaum kapitalis mempergunakan kekuasaan ekonomi mereka dengan suatu sistem pasar komersial untuk menjamin aliran informasi publik sesuai dengan kepentingan mereka. Dari data Milestone Kompas Gramedia 2007-2020 dan Roadmap korporat 2008-2010, mulai dari milestone pertama, kedua, ketiga, dan keempat sangat jelas terlihat bahwa Kelompok Kompas Gramedia memiliki obsesi menjadi pemain global dalam bisnis media dan di luar media, tidak hanya di Indonesia tapi juga di kawasan Asia Tenggara. Setiap unit bisnisnya harus mencapai sinergi seoptimal mungkin melalui ekspansi pasar oleh beragam unit bisnisnya tersebut, dalam rangka peningkatan laba korporat agar dapat mencapai angka peningkatan berkali lipat dari sebelumnya.

Bila dikaitkan dengan perspektif instrumentalis yang memberikan penekanan pada determinisme ekonomi, di mana segala sesuatu pada akhirnya akan 
dikaitkan secara langsung dengan kekuatan-kekuatan ekonomi dan Kelompok Kompas Gramedia merupakan instrumen dari kelas yang mendominasi. Dalam hal ini kapitalis dilihat sebagai pihak yang menggunakan kekuatan ekonominya untuk segala kepentingannya, dalam sistem pasar komersial untuk memastikan bahwa arus informasi publik sesuai dengan kepentingannya, dan untuk mendapatkan keuntungan yang semakin merangkak naik. Hingga luas dan besarnya kepemilikan media di tangan konglomerat atau pemegang kekuasaan, telah membuat media menjadi lebih terintegrasi pada kepentingan pemilik, serta memperdalam ikatan mereka dengan kepentingan kelaskelas kapitalis.

Ekonomi politik memiliki dua varian dan permasalahan spasialisasi dan praktek konglomerasi yang dilakukan oleh Kelompok Kompas Gramedia ini lebih relevan apabila di analisa menggunakan perspektif kritis. Menurut Golding dan Murdock perspektif ekonomi politik kritis menganalisa dan memperhatikan perluasan "dominasi" perusahaan media, baik melalui peningkatan kuantitas dan kualitas produksi budaya yang langsung dilindungi oleh pemilik modal. Ekstensifikasi dominasi media dikontrol melalui dominasi produksi isi media yang sejalan dengan preferensi pemilik modal. Perspektif ekonomi politik kritis melihat persoalan ekonomi dalam hubungan dengan kehidupan politik, sosial, dan budaya. paradigma kritis memberikan penekanan pada relasi sosial (social relations) dan kekuasaan (power). Spasialisasi sendiri merupakan sebuah sistem konsentrasi yang memusat, dan jika kekuasaan tersebut memusat, maka akan terjadi hegemoni. Hegemoni merupakan globalisasi yang terjadi karena adanya konsentrasi media, pihak yang mempunyai kuasa untuk menghegemoni media, yaitu negara, pengusaha, media sendiri, serta civil society. Kemenangan kapitalisme menjadi konsekuensi logis ter-hegemoninya media oleh modal. Hegemoni modal seakan tumpang tindih dengan kepentingan politik. Ini karena para pemilik media besar di Indonesia, selain mempunyai kekuatan modal, sekaligus menempati posisi strategis politik nasional.

\section{Rantai Nilai Produk Media (Media Product Value Chain)}

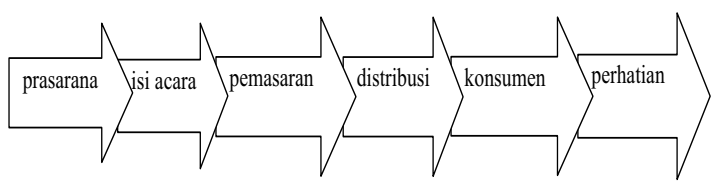

Gambar 4. Media Product Value Chain

Penjelasan Rantai Nilai Produk Media (Media Product Value Chain) sebagai berikut: (1) Prasarana (infrastructure), yaitu penguasaan dan akses kepada teknologi informasi dan komunikasi ICT, (2) Isi acara (content), sebuah kreativitas mengubah paradigma produksi, (3) Pemasaran (marketing), yaitu aktivitas riset pasar dan riset konsumen secara berkelanjutan, (4) Distribusi (distribution), ialah penguasaan dan akses transportasi dan logistik atau prasarana dan teknologi, (5) Langsung ke konsumen (retail), cara penyiaran yang memuaskan, menarik, dan tidak basi, (6)Perhatian (attention), acara yang menarik bagi konsumen maupun pemasang iklan.

\section{Praktik Konglomerasi Kelompok Kompas Gramedia dan Hilangnya Diversity of Content}

Dilihat dari sudut pandang ekonomi-politik media, kondisi media kontemporer ditandai dengan meluasnya konsentrasi dan konglomerasi media. Perluasan atas konsentrasi dan konglomerasi media ini juga pararel dengan konvergensi media. Di satu sisi tumbuh media dalam berbagai lini yang berbeda, namun di sisi yang lain, kepemilikan dari media semakin memusat pada segelintir orang saja. Kelompok Kompas Gramedia berupaya terus membangun kerajaan bisnisnya dengan memperluas jaringan kekuasaannya. Padahal salah satu hak yang harus didapat masyarakat dari media adalah, diversity of content atau 
keanekaragaman isi dari informasi atau pemberitaan. Konsentrasi media yang terjadi dikhawatirkan membawa sejumlah dampak negatif, tidak hanya pada perkembangan kelangsungan sistem media di Indonesia, melainkan juga dampak pada isi atau konten yang disampaikan kepada masyarakat.

Praktek Konglomerasi media seperti yang dilakukan Kelompok Kompas Gramedia ini sangat tidak sehat dalam iklim berdemokrasi dan perpolitikan bangsa ini, mengingat pengaruh media yang begitu kuat terhadap kognitif khalayak. Mengacu pada Jurgen habermas yang menyatakan bahwa media massa sesungguhnya adalah sebuah Public Sphere yang semestinya dijaga dari berbagai pengaruh dan kepentingan, dan media seharusnya dapat menjadi The Market Places Of Ideas tempat penawaran berbagai gagasan sebagaimana setiap konsep pasar, yang mana hanya ide terbaik sajalah yang pantas dijual dan ditawarkan. Bentuk konglomerasi media dengan terpusatnya kepemilikan media massa oleh para penguasa modal seperti yang dilakukan Kelompok Kompas Gramedia, dapat berimplikasi terhadap obyektivitas media dalam menyampaikan muatanmuatan informasinya. Konglomerasi media menjadikan orientasi media cenderung ke arah industri, bukan kearah fungsi jurnalismenya. Akibatnya adalah, media lebih mengutamakan tayangan informasiinformasi yang menarik saja daripada informasi yang penting untuk audiensnya.

\section{Dampak Praktik Konglomerasi Media}

Eoin Devereux menuliskan beberapa fakta mengenai kritik dan dampak atas praktik konglomerasi media. Pertama, secara progresif terjadi konsentrasi kepemilikan media massa oleh segelintir transnational multimedia conglomerates. Jakob Oetama adalah salah satu konglomerat media yang menguasai berbagai media di berbagai lini. Kedua, faktanya, banyak dari konglomerat ini yang memiliki, mengontrol atau mempunyai kepentingan substansial dalam perusahaan media dan non media. Hal ini dapat menimbulkan konflik kepentingan, antara kepentingan jurnalistik untuk memberitakan secara fair dengan kepentingan pemilik perusahaan, yang mengharapkan lini usaha non medianya tidak menjadi bulan-bulanan di media miliknya sendiri jika sang pemilik media tersandung masalah.

Ketiga, berlanjutnya perdebatan tentang peran ruang publik media yang muncul dari konsentrasi dan konglomerasi yang lebih besar. Peran ruang publik ini menjadi penting karena konsentrasi dan konglomerasi media menyebabkan penguasaan informasi di tangan segelintir orang. Keempat, konsekuensi dari berita, current affairs dan jurnalisme investigasi ke arah hiburan, populisme dan infotainment. Corak produksi (mode of production) dalam manajemen media yang mengabdi kepada kepentingan modal akan menjadikan pemujaan yang berlebihan terhadap rating dan iklan, sehingga selera pasar yang kemudian diikuti.

Kelima, redefinisi audiens sebagai konsumen bukan lagi warga (citizen). Ini terjadi dikarenakan proses industrialisasi budaya (cultural industries) yang terjadi secara massif. Keenam, akses yang tidak setara terhadap isi media dan teknologi media, yaitu fakta ironis tentang perubahan struktur manajemen media yang menyebabkan khalayak menjadi terpecah, antara yang memiliki akses media (the have) dan yang tidak memiliki akses media (the have not). Ketujuh, kekuatan ekonomi politik dari individu yang menguasai kekaisaran media (Devereux,2003:54). Di Indonesia, corak manajemen media pun semakin mengarah menuju bentuk ini, konglomerasi media kemudian menjadi fenomena lazim dalam model struktur sosial yang liberal. Kekaisaran media yang dibangun Jakob Oetama adalah fakta dari dominasi individu 
dalam bisnis media, hal ini bisa dilihat dari dominasi Kelompok Kompas Gramedia (KKG) yang menguasai pangsa pasar media cetak di Indonesia. Kompas bahkan secara ekspansif mengembangkan edisi online-nya untukmendukung edisicetaknya.

Jadi kepemilikan media maka akan berakibat dengan berubahnya kebijakan dan tujuan media itu sendiri. Adanya konsentrasi media massa juga dapat mengakibatkan homogenitas pemberitaan dan informasi akibat dari diversifikasi media, yaitu proses penganekaragaman usaha ekonomi sosial yang dilakukan oleh suatu industri atau pelaku produksi media. Masyarakat akan sulit untuk mencari referensi lain dan sulit untuk melihat sisi lain dari suatu kasus yang diangkat oleh pemberitaan media massa karena homogenitas tersebut akibat kepemilikan yang berpusat.

Sebagai contoh Harian Warta Kota dan Harian Surya akan memiliki sudut pandang yang sama terhadap suatu kasus. Masyarakat hanya akan dicekoki berita dan informasi yang itu-itu saja. Ketika masyarakat mencoba untuk beralih dari suatu media ke media lain, yang akan tetap mereka temui adalah pemberitaan yang serupa karena faktor kepemilikan yang sama. Konsolidasi media mampu menghilangkan keberagaman informasi yang akan diterima oleh masyarakat. Hal itu terjadi karena adanya monopoli dan sentralisasi infomasi. Karena kepemilikan yang sama, media massa cenderung menyebarluaskan informasi dan programprogram yang sejenis.

Pada akhirnya, akibat paling parah dari situasi sentralisasi informasi adalah terciptanya masyarakat yang apatis dengan proses politik yang berkembang. Karena kepentingan ekonomi media massa yang sudah berkembang, maka pers akan berubah, tidak lagi menjadi pers yang idealis karena ada campur tangan pemilik media yang akan menjadi gatekeeper utama dalam menentukan informasi dan opini "pilihan" untuk diterima oleh masyarakat luas. Hal ini akan membuat informasi yang sampai ke masyarakat telah diatur sedemikian rupa tanpa disadari dan menjadi tidak seimbang. Adanya pengaruh pemilik media terhadap isi program media massa sangat berimbas kepada khalayak. Khalayak dihadapkan pada minimnya alternativ pilihan sumber informasi karena informasi yang ada sudah dikuasai oleh segelintir kelompok tertentu yang seringkali informasi tersebut bersifat bias.

Selain itu, dalam suatu berita yang paling penting untuk disampaikan adalah adanya kebenaran yang menyangkut akurasi (didasari oleh bukti nyata, keraguan harus tetap diberitahukan kepada publik, mengutip harus sesuai dengan sumber, persaingan kadang menurunkan kualitas pemberitaan), memberikan pemahaman publik (pemberitaan harus menyeluruh, informasi lengkap, sumber jelas, tidak memihak) serta jujur, adil, dan berimbang menghindari informasi yang bias. Ketika sumber informasi sudah dikuasai oleh pihak-pihak yang memiliki kepentingan tertentu, maka kebenaran yang ada ikut tersembunyikan. Khalayak tidak lagi dapat memperoleh haknya akan kebenaran informasi yang ada dan mengakibatkan terjadinya distorsi informasi bagi publik. Ketika masyarakat membutuhkan fakta yang sebenarnya, justru banyak pemberitaan yang berupaya menyembunyikannya. Hal tersebut menyebabkan kepercayaan publik sebagai konsekuensinya.

Semua itu tidak terlepas dari adanya agenda setting dan framing yang dilakukan media massa yang disesuaikan dengan kepentingan pemiliknya. Hal tersebut bertentangan dengan fungsi utama jurnalisme media, yakni menyampaikan kebenaran publik, bukan kebenaran subyektif pemilik media atau pasar yang sifatnya sensasional. Kenyataan 
menunjukkan, keterlibatan media dalam membentuk suatu opini publik adalah sebuah kekuatan tersendiri yang dimilikinya dan itu sangat berpengaruh dalam tatanan kehidupan di masyarakat. Konglomerasi media dimana pemilik media besar yang memiliki beragam jenis media massa dapat secara terus-menerus menyampaikan informasi walaupun informasi tersebut sarat dengan kepentingan ekonomi dan politik tertentu. Ketika masyarakat terus menerus diinternalisasi dengan informasi tersebut dan masyarakat tidak memiliki ruang dan waktu cukup untuk berpikir, maka yang terjadi orang tidak lagi peka membedakan mana yang benar atau tidak.

\section{Efisiensi}

Efisiensi memiliki Peranan yang sangat penting, dan inilah yang menjadikan industri media massa berkembang sangat pesat dan membuat media massa tidak hanya sebagai sebuah institusi yang idealis, seperti misalnya sebagai alat sosial, politik, dan budaya, tetapi juga telah merubahnya menjadi suatu institusi yang sangat mementingkan keuntungan ekonomi. Sebagai institusi ekonomi, media massa hadir menjadi suatu industri yang menjanjikan keuntungan yang besar bagi setiap pengusaha. Hal itu mengakibatkan pengusaha media kini tidak lagi hanya sekedar berorientasi pada pemenuhan hak masyarakat akan terpenuhinya informasi, tetapi juga berorientasi untuk mengejar keuntungan ekonomi sebesar-besarnya. Merger oleh perusahaan-perusahaan media, dinilai menjadi pilihan yang tepat untuk melakukan efisiensi dan juga dianggap sebagai strategi terbaik untuk menyehatkan kondisi keuangan yang berat karena menghadapi persaingan yang ketat. Merger menjadi fenomena umum. Karena karakeristik para pengusaha di manapun, ada kecenderungan sama, yaitu selain menerapkan efisiensi, mereka juga berupaya memperbesar jaringan usahanya, kemudian mengakumulasikan keuntungan dan modal untuk kepentingan mereka. Mengatasnamakan efisiensi, tuntutan industri, dan neoliberal spirit, konsentrasi itupun tetap saja berlangsung, dan semakin menjadi-jadi.

Perkembangan bisnis ini berkembang melalui pembangunan skala ekonomi yang bertujuan untuk meningkatkan keuntungan dari pasar yang lebih luas. Kelompok Kompas Gramedia mengikuti model ekonomi industrial yang ditandai dengan akselerasi banyaknya media dan hasilhasilnya untuk mendapatkan biaya yang murah untuk produksinya atau efisiensi. Pasar media merupakan suatu pasar yang memiliki karakteristik yang unik bila dibandingkan dengan jenis pasar lainnya. Media tidak hanya memproduksi suatu barang, tetapi media juga memproduksi jasa. Barang yang ditawarkan adalah isi program dari media itu sendiri, dan jenis jasa yang ditawarkan adalah media massa sebagai medium untuk menghubungkan antara pengiklan dengan khalayak pengkonsumsi media massa. Media massa mencoba untuk mencari jalan untuk mengefisien dan mengefektifkan produksi mereka agar keuntungan yang mereka peroleh dapat maksimum.

Menghadapi persaingan yang sangat ketat dalam bisnis media massa yang memerlukan kekuatan sosial ekonomi ini, maka terjadi kecenderungan konsolidasi media yang kemudian mengarah kepada munculnya kelompok pemain raksasa media massa yang kemudian mengakibatkan terjadinya konsentrasi kepemilikan media massa. Praktek efisiensi yang dilakukan oleh Kelompok Kompas Gramedia contohnya adalah integrasi vertikal dilakukan untuk mengamankan kontrol dari sisi aset, distribusi, eksibisi dll, serta efisiensi dari sisi content. Pola fikir bisnis media yang efisien adalah memiliki jalur sendiri, memiliki percetakan sendiri, 
dari awal hingga proses distribusi hasil produksi kepada konsumen. Kelompok Kompas Gramedia memiliki semua lahan bisnis yang berkaitan satu sama lain dan dapat saling menunjang dari hulu hingga ke hilir, yang belum dimiliki Kelompok Kompas Gramedia hanya pabrik kertas dan lahan perkebunan kayu sebagai bahan baku kertas.

Pemerintah Indonesia yang telah melihat akan potensi merugikan dari adanya konsentrasi suatu perusahaan mencoba mengintervensi dengan menghadirkan sejumlah peraturan yang mengatur mengenai kepemilikan perusahaan namun pengusaha mampu melihat dan memanfaat celah-celah kebolongan dari regulasi yang ada untuk dapat membuat sejumlah strategi, termasuk strategi konsentrasi media guna memperoleh keuntungan yang sebesarbesarnya. Penyatuan kebijakan sirkulasi dalam satu manajemen seperti dilakukan Kompas memang menguntungkan. Disamping merupakan suatu bentuk efisiensi, juga untuk meningkatkan posisi tawar di mata agen dan pengiklan.

Media massa kini berusaha untuk mencari pengeluaran minimal demi mendapatkan penghasilan yang maksimal, hal inilah yang kemudian mendorong terjadinya komersialisasi media massa. Konsentrasi dari pemilik media juga merupakan hal yang penting untuk dilihat dalam menentukan struktur pasar media. "...the concentration of sellers is the most important factor because it determines a great deal of the structure of a market, and most researchers use this criterion to define the type of market structure" (Lin and Chi, 2003). Konsentrasi kepemilikan media massa di Indonesia mengakibatkan struktur pasar media massa Indonesia memiliki bentuk oligopoli, yaitu kondisi yang hanya terdapat sejumlah pemain besar dalam industri media massa dengan produk yang terdiferensiasi.
Dalam pasar oligopoli, tindakan yang dilakukan oleh salah satu pemain pasar akan mempengaruhi pemain lainnya, baik dalam kebijakan maupun performa dari pemain lain. Selain itu, apabila ada pemain baru yang hendak memasuki pasar, maka akan sulit untuk memasuki pasar tersebut apabila tidak memiliki kemampuan atau kekuatan yang sama dengan pemain yang telah ada sebelumnya yang telah memiliki teknologi dan pengalaman yang lebih kuat, karena persaingan yang terjadi tidak hanya persaingan isi dan jenis program tapi juga persaingan infrastruktur dan teknologi. Sulitnya memasuki pasar tersebut mengakibatkan konsentrasi akan semakin memusat pada pelaku pasar yang kuat.

Dari sekian motif ekonomi yang muncul dalam sebuah industri media massa, yang paling pokok adalah motif keuntungan. Faktor keuntungan adalah faktor yang mengoperasionalisasikan industri media sampai ke organisasiorganisasinya. Faktor keuntungan ini yang sering bertabrakan dengan masalah kepentingan publik yang juga diemban oleh media massa dan faktanya kekuasaan modal memiliki kekuatan yang bisa saja lebih dashyat daripada kekuasaan negara itu sendiri dan kekuasaan modal bisa berkolaborasi dengan jenis kekuasaan apapun dan jenis kapitalis apapun. Industri media termasuk salah satu yang mengalami keberuntungan dengan perubahan situasi ini karena dengan deregulasi dan liberalisasi yang terjadi dalam sektor media, maka mereka segera menjadi kapitalis-kapitalis baru atau semakin memperkuat posisi mereka untuk tumbuh di Indonesia.

\section{Simpulan}

Konsentrasi media dan pemilik media itu sendiri sangat berpengaruh terhadap isi atau program yang disampaikan kepada masyarakat dimana isi atau program tersebut merepresentasikan kepentingan ekonomi maupun politik pemilik media. 
Akibatnya kepentingan masyarakat untuk mendapatkan kebenaran menjadi hilang. Semua itu karena adanya proses agenda seting dan framing yang dilakukan oleh media yang disesuaikan dengan kepentingan pemilknya. Kebenaran yang tidak didapatkan masyarakat tersebut dapat menyebabkan masyarakat terhegemoni dengan menerima kebenaran versi media massa. Selain itu, pengaruh lainnya adalah kesempatan masyarakat untuk mendapat informasi alternatif yang lebih berimbang sulit untuk didapatkan karena telah terjadi kepemilikan atas beragam media oleh segelintir kelompok tertentu yang berakibat pada terjadinya homogenisasi informasi.

Perspektif ekonomi politik melihat bahwa media tidak lepas dari kepentingan baik kepentingan pemilik modal, negara atau kelompok lainnya. Proses dominasi ini menunjukkan adanya penyebaran aktivitas komunikasi massa yang sangat dipengaruhi oleh struktur ekonomi politik masyarakat yang bersangkutan. Kajian ekonomi politik menempatkan media sebagai instrumen dominasi yang dapat digunakan oleh pemilik modal atau kelompok penguasa lainnya untuk memberikan arus informasi publik sesuai dengan kepentingannya dalam sistem pasar komersial.

Spasialisasi merupakan sebuah sistem konsentrasi yang memusat berkaitan dengan bagaimana subsistem-subsistem disentralkan sehingga apa yang muncul di media didominasi pemilik media yaitu para kapitalis media. Fenomena konsentrasi dan konglomerasi media berjalan seiring dengan terjadinya revolusi teknologi penyiaran dan informasi, korporasi-korporasi media terbentuk dan menjadi besar dengan cara kepemilikan saham, penggabungan dalam joint-venture, pembentukan kerjasama, atau pendirian kartel komunikasi raksasa yang memiliki puluhan bahkan ratusan media. Konsentrasi dan konglomerasi media memungkinkan terjadinya privatisasi media.
Pemikiran perspektif ekonomi politik dalam ranah manajemen media bukanlah semata-mata fenomena bisnis, melainkan fenomena ekonomi-politik yang melibatkan kekuasaan. Kepemilikan media, bukan hanya berurusan dengan persoalan produk, tetapi berkaitan dengan bagaimana lanskap sosial, pencitraan, berita, pesan dan kata-kata dikontrol dan disosialisasikan pada masyarakat, misalnya Kondisi yang terjadi di Indonesia. Teori Ekonomi politik mengedepankan pada keinginan yang kuat untuk memahami dan mengkritisi implikasi dari konsentrasi media dan praktek konglomerasi. Berdasarkan perspektif ini, konsentrasi dan konglomerasi memiliki implikasi yang serius pada isi media (terutama genre faktual, seperti berita, dokumenter,dan current affairs) dan audiens media, audiens dikonstruksikan lebih sebagai konsumen daripada sebagai warga yang berhak mendapatkan informasi.

Dengan adanya konglomerasi, maka adanya efisiensi yang dilakukan media tergambar pada rantai nilai produk media (media product value chain), media juga tidak bisa mengelak mengenai isi pemberitaan yang akan cenderung sama, walaupun bisa saja hanya terjadi pada saat-saat tertentu saja (monopoli isi media). Dengan penyamaan atas isi media ini, masyarakat sebagai audiens tidak memiliki kebebasan untuk memilih content media sesuai dengan yang mereka inginkan dan tidak ada lagi diversity of content. Kelompok Kompas Gramedia mengikuti model ekonomi industrial yang ditandai dengan akselerasi banyaknya media dan hasil-hasilnya untuk mendapatkan biaya yang murah untuk produksinya atau efisiensi. Hal ini juga akan sangat berkaitan erat dengan tumbuhnya semangat kapitalisme dalam industri media. Industri media yang dibangun dengan semangat kapitalisme tentu akan menghasilkan pesan atau produk media yang berorientasi pada bertambahnya modal. Selain itu isi media menjadi kurang 
berkualitas dan hanya mementingkan keuntungan semata.

Besarnya kekuasaan yang dimiliki oleh sang kapitalis atas seluruh kekayaan negeri, merupakan suatu perubahan yang bersifat total dalam persoalan hak milik (right of property), dan serangkaian undangundang apakah yang dapat memungkinkan terjadinya perubahan secara menyeluruh? (Marx, 2009:72). Dalam perkembangan industri media, pemerintah seharusnya dapat berperan aktif menjadi regulatory body, meski ada tendensi yang sangat besar dan kerap muncul menentang fungsi regulatory dari pemerintah yang sering dikaitkan dengan intervensi pemerintah pada industri media. Poin pentingnya adalah pemerintah harus dapat berperan aktif sebagai pengatur kepentingan publik.

\section{Daftar Pustaka}

Biagi, Shirley. (2010). Media Impact Edisi ke Sembilan. Jakarta:Salemba Humanika. Chomsky, Noam dan Edward S. Herman. (1988). Manufacturing Consent, Pantheon Books.
Golding, Peter and Graham Murdock. (1997). The Political Economy of The Media volume 1. US: An Elgar Reference Collection.

Marx, Karl. (2009). Membongkar Akar krisis global. Yogyakarta: Resist Book.

McQuail, Denis. (1987), hlm. 40. Teori Komunikasi Massa, Agus Dharma (terj.). Jakarta: Erlangga.

Mosco, Vincent. (2009). Political Economy of Communication Second Edition. London: Sage Publication.

\section{Internet}

Kompasgramedia.com http:/ /hr.kompasgramedia.com/Co mpanyProfile.php?id=20101007160.

Kompasiana.com http:/ / ekonomi.kompasiana.com/m anajemen/2010/06/16/media-diindonesia-intervensi-modal-dankepemilikan-dalam-regulasi-danpemberitaannya/. 